\title{
EFFECT OF REMEDIAL TEACHING USING CURATIVE APPROACH ON IMPROVEMENT OF STUDENT LEARNING OUTCOMES AT SUBJECT OF AL-QUR'AN HADITS IN MTs. MUHAMMADIYAH WARU BAKI SUKOHARJO
}

\author{
Nur Ardiyansyah \\ Nurardiyansyah_2018@gmail.com
}

\begin{abstract}
This study aims to discuss how remedial teaching using curative approach in MTs. Muhammadiyah Waru Baki, Sukoharjo, how the student learning outcomes of Qur'an Hadits subjects in MTs. Muhammadiyah Waru Baki, Sukoharjo, and, whether there is any influence of remedial teaching using the curative approach in improving student learning outcomes of Qur'an Hadits subjects in MTs. Muhammadiyah Waru Baki, Sukoharjo. This research is quantitative. The research conducted by the researcher is also a causal nature of comparative research focused on comparing the free variables of some subjects who received a different influence of the independent variables in order to know the effect of remedial teaching using curative approach in improving the student learning outcomes in Qur'an Hadits subjects in MTs. Muhammadiyah Waru Baki, Sukoharjo, namely to test the hypothesis of data pairs using the formula t-test (sample paired $t$-test). Based on the mentioned problems above and after analysed, it can be concluded that (1) Implementation of remedial teaching in MTs. Muhammadiyah Waru Sukoharjo Baki is $71.9 \%$, which means "good enough". (2) The results of the students' learning experience increase $68.46 \%$ from the average value of 69.46 into 85.37 with a percentage increase of $23 \%$. (3) From the calculation of normality test and paired sample t-test is resulted that arithmetic $\mathrm{t}>\mathrm{t}$ table or $19.025>2.001$ namely reject $\mathrm{H} 0$ and received $\mathrm{H} 1$, which means there are significant remedial teaching using curative approach to improve the student learning outcomes in Qur'an Hadits subjects in MTs. Muhammadiyah Waru Baki, Sukoharjo
\end{abstract}

Keywords: Remedial, Curative and Learning Outcomes

\section{A. INTRODUCTION}

Education plays an important role in developing human potential. This is in accordance with Law No.20 of 2003 on the national education system in Chapter II, Article 3 states that:

"The national education serves to develop the ability and character development and civilization of the nation's dignity in the context of the intellectual life of the nation, is aimed at developing students' potentials in order to be man of faith and fear of God Almighty, noble, healthy, knowledgeable, skilled, creative, independent, and become citizens of a democratic seta responsible ". ${ }^{1}$

The aim is to develop human potential through a process of education, one of which is done through the school. School is an institution that runs the educational process by providing

\footnotetext{
${ }^{1}$ Undang-undang Republik Indonesia No. 20 Th. 2003 BAB II Pasal 3 Tentang Sistem Pendidikan Nasional, (Bandung: Fermana, 2003), 56.
} 
teaching her students. The students are the main subject in education. ${ }^{2}$ Thus, learning is the most basic activity for the study will be able to ennoble us as human beings. As word of Allah in Surah al-Mujadalah verse 11: "... Allah will exalt those who believe among you and those who were given some degree of knowledge". (Surat al-Mujadalah: 11). ${ }^{3}$

Learning is a process that a person attempt to acquire a new behavior changes as a whole, as a result of his own experience in interaction with the environment. ${ }^{4}$ The achievement of learning objectives is marked by a change in behavior. This means that the success or failure of education goals a lot depends on how the learning process experienced by students as a protégé. But in the reality, some schools are often encountered a number of students who received study results far below the average set. $^{5}$

A teacher must know the whereabouts of his protégé in capturing and paying attention during the course of the learning process in the classroom, for the next material master is also necessary to understand the characteristics of the students. For indeed, every student achieve learning success has different abilities. There are many students who can achieve it without difficulty, but many students have difficulties. Difficult students achieve good learning outcomes at school, but had to follow the lessons in

\footnotetext{
${ }^{2}$ Syaiful Bahri Djamarah, Psikologi Belajar, (Jakarta: Rineka Cipta, 2002), 46.

${ }^{3}$ Muhammad Hambal. 2018. Halaqah Tradition in Building Rabbani Characters in Pesantren Al-Islam Lamongan, East Java, Indonesia. Jurnal Studia Religia, Vol. 2, No. 1

4 Slameto, Belajar dan Faktor-Faktor yang Mempengaruhinya, (Jakarta : Rineka Cipta, 2003), 2.

${ }^{5}$ Muhammad Hambal. 2015. "Deresan"

Program the Mastery of Arabic-Classic Book at Pondok Pesantren Karangasem Lamongan
}

earnest. Even students who add additional learning at home, but the results are still unsatisfactory. Thus, educators must act helped to solve the problems faced by students. The teacher is responsible for helping students to achieve the learning objectives, so that it can give them the opportunity to improve their learning outcomes. ${ }^{6}$

Learning disabilities are problems that need to be tackled carefully. Repetition of incomplete learning difficulties makes a barrier to children's development. A variety of techniques and forms of overcoming difficulties need to be implemented with regard to the fundamental. ${ }^{7}$ Therefore, if there are students who study results are less good, then the teacher should allow time for the students, for example by providing remedial teaching and approaches which can certainly motivate the students more active in learning.

As, the remedial teaching is the teacher effort to create a situation that allows individuals or groups of students with particular characteristics to be able to develop itself as optimal as possible so as to meet the success criteria minimum expected with through a process of interaction planned, organized, and directed by more attention to the level of conformance to the diversity of objective conditions of individuals or groups of students are concerned. ${ }^{8}$

Remedial Teaching Program began organized through government

East Java Indonesia. Journal of Social Sciences and Humanities, Vol. 1, No. 2, pp. 125-130

6 Oemar Hamalik, Perencanaan pengajaran, (Jakarta: Bumi Aksara, 2002), 234.

${ }^{7}$ Martini Jamaris, Kesulitan belajar: Perspektif, asesmen, dan penanggulangannya bagi anak usia dini dan usia sekolah, (Bogor: Ghalia Indonesia, 2014), 61.

8 Abin syamsuddin makmun, Psikologi kependidikan, (Bandung: PT. Remaja Rosdakarya, 2012), 343. 
policies and aspirations grains incorporated into the Education Act. Remedial Teaching gives good wishes to pupils or students who have learning difficulties. Due to if learning difficulties are not taken seriously, the failure will be experienced forever. ${ }^{9}$ Suharsimi define remedial program is an activity that is awarded to students who have not mastered the lesson material you have provided teachers with the intention of enhancing the mastery of materials, so that students are expected to achieve the learning objectives that have been determined to achieve mastery learning which will be good for student achievement. ${ }^{10}$

Curative approach in remedial teaching was held to remember the fact there someone or some students are unable to complete the program perfectly fit the criteria for success in the learning process. Programs in the process can be defined for each meeting, the lesson unit, or units of a certain set time. In student learning difficulties cannot be classified, there are several ways to remedy. If numerous, they are given instruction simultaneously. Meanwhile, if the amount is small, they can be taught individually.

Limitation of remedies according to the Good (1973) is defined as follows:"Classis a specially selected remedial groups of pupils in need of more intensive instruction in some areas of education than is possible in the regular classroom." Remedial classes are specially selected grouping students who require more teaching on specific subjects of the students in the regular classroom. A class act in the form of teaching back with instructional

\footnotetext{
9 Cece Wijaya, Pendidikan Remidial Sarana Pengembangan Mutu Sumber Daya Manusia, (Bandung: PT. Remaja Rosdakarya, 2010), 46.

${ }^{10}$ Suharsimi Arikunto, Pengelolaan Kelas dan Siswa, (Surabaya: Rajawali pers, 1996), 67.
}

materials that may be repeated or supplementation with the issue and exercise generally is included coverage teachers' teaching methods. Remedies generally include an understanding of individual students' needs, coupled with the right teaching methods prepared by the teachers to assist students in achieving the learning objectives that have been set. ${ }^{11}$

In MTs Muhammadiyah Waru Baki Sidoarjo, the school had implemented remedial teaching and has the objective to improve the shortcomings of individual student learning outcomes are different and to meet the needs of students who experience difficulty in achieving learning outcomes are balanced.

This case of Remedial Teaching practice will have a different concept in accordance with the level of difficulty faced by students in understanding, understand and practice the subject matter. Therefore, educators have a special role in helping students who have difficulty in learning, especially on the subjects of Qur'an Hadits which is regarded as an easy lesson, but a bit difficult, it takes patience and perseverance of the teachers concerned to lessons delivered understandable and practiced.

For that reason, the researcher wanted to examine more deeply related "Influence of Remedial Teaching using Curative Approach on Improvement of Student Learning Outcomes at Qur'an Hadits Subject in MTs Muhammadiyah Waru Baki, Sukoharjo".

\section{B. METHODS}

\footnotetext{
${ }^{11}$ Sukardi, Evaluasi pendidikan prinsip dan operasionalnya, (Jakarta: Bumi Aksara, 2012), 228
} 
Research is an activity undertaken to acquire knowledge of the truth of a scientific nature through a predetermined procedure to reach the truth. This type of research is a field research or scene (field research), the research conducted in the field of data collection, such as in the community, institutions and community organizations, and educational institutions, both formal and non-formal.

Field research referred to in this paper is a quantitative research. Quantitative research is a process of research to find the knowledge to use the data is numeric (statistical analysis) as a tool to find information and truth about what he wants to know. ${ }^{12}$

Quantitative research is a study which basically uses deductiveinductive approach. This approach departs from a theoretical framework, the idea of experts, as well as understanding the researcher based on his experience, then developed into problems along with problem-solving proposed for justification (verification) in the form of support or rejection of empirical data in the field.

According Margiono, quantitative research is a process of determining the data in the form of knowledge which uses numbers as a means of finding information about what we want to know. ${ }^{13}$ Meanwhile, according to Arikunto Suharsimi, quantitative approach is an approach that is widely demanded use of numbers, ranging from data collection, interpretation of these data, as well as the appearance of the results. ${ }^{14}$ In quantitative research statistical test is absolutely necessary in analyzing the data obtained and to test the hypothesis.

\footnotetext{
${ }^{12}$ Margono, Metode Penelitian Pendidikan, (Jakarta: PT Rineka Cipta, 1997), 105.

${ }^{13}$ Margono, Metodologi Penelitian, (Jakarta: Rineka Cipta, 2003), 105.
}

This study uses a quantitative approach. Quantitative research is research that uses data in the form of figures collected as a result of the study, and analyzed using statistical methods. A quantitative approach in this study is to analyze the data, which is then analyzed by parametric statistic by using the $\mathrm{t}$-test (sample paired $t$-test). ${ }^{15}$

In addition, the research conducted by the researcher is also a causal nature of comparative research focused on comparing the free variables of some subjects who received a different influence of the independent variables. The influence of the independent variables on the dependent variable is not due to the treatment of researchers, but has been going on before the study is done.

This research was conducted in MTs Muhammadiyah Waru Baki, Sukoharjo. The researcher chose this place because the school has implemented programs related to the title of researchers, and also of its territory located and easily accessible to researchers, so hopefully this research can proceed smoothly in the future.

The source of the data in this study includes:

a. Primary source is a data source that directly provides data to data collectors (Sugiyono, 2012: 225). The primary source of this form of notes of interviews obtained through interviews conducted by the author. Informant or informants in this study is the teacher of the Qur'an and Hadits.

b. Secondary data source is a data source that does not provide information directly to the data collector. This secondary data

\footnotetext{
${ }^{14}$ Suharsimi Arikunto, Prosedur Penelitian suatu Pendekatan Praktek, (Jakarta: Rineka Cipta, 2006), 12.

${ }^{15}$ Margono, Metodologi penelitian, 103.
} 
source can be a result of further processing of primary data presented in another form or from any other person (Sugiyono, 2012: 225). Data obtained from the documents and archives directly to the field. Which included here is based on secondary data documentation and data from student questionnaires. The researcher also uses secondary data from the literature and the results of other data sources that support, as well as on the literature- literature and websites on the internet with regard to research.

\section{RESULTS AND DISCUSSION}

1. Implementation of Remedial Teaching at the Qur'an Hadits subject in class VIII of MTs Muhammadiyah Waru Baki Sukoharjo

Implementation of Remedial

Teaching strives to help students achieve maximum learning achievement results. Then in accordance with the purpose of the remedial teaching whose main goal to help students and is expected to accelerate the helpful process and can compensate accomplishments achieved by classmates.

Mrs. Fathin Suryaning, S Ag is the teacher of the Quran Hadits at class VIII of MTs Muhammadiyah Waru Baki, Sukoharjo. According to his interviews, the implementation of Remedial Teaching, especially on the subjects of Qur'an Hadits it is already running. As descriptions of interviews with the subject teachers of Qur'an Hadits as follows: "Remedial teaching on Qur'an Hadits subjects often implemented because of the difficulty level of different students. For example,

16 Ibu Fathin Suryaning, S Ag, Guru Qur'an Hadits Kelas VIII MTs Muhammadiyah Waru Baki Sukoharjo, 25 Desember 2017. students have difficulty in reading and writing of the Qur'an caused by their school background is different. There resulting from the Madrasah and also from elementary school did not have a foundation (basic) on religion will have difficulty studying religion. Therefore, one way that teachers do with holding Remedial (repetition) lessons for students experiencing difficulty in understanding ". ${ }^{16}$

From the above statement can be concluded that the background of the students is different, there are derived from public schools and madrasah it will cause a difference in the level of intelligence of students. For school students in Madrasah it should have understood the religious subjects, especially on the subjects of Qur'an and Hadits. However, it is different from public school students who have never studied religion and it will have difficulty in studying religion. Therefore, one way to be taken is by the Remedial Teaching.

Learning remedial is given after learners go through SK consisting of some KD. It is based on the consideration that SK is a capabilities determination that consists of several KD. Thus, those who have not yet reached the mastery of certain SK need to follow the remedial program.

MTs Muhammadiyah Waru Baki, Sukoharjo has many students whose value is below the standard. KKM (minimum completeness criteria) for learning the Qur'an Hadits specified in this school is 78. If the value of those under 78, they must follow the remedial program. The regulation is conducted so that the students in MTs Muhammadiyah Baki, Sukoharjo study harder and do not underestimate the religious studies. 
Remedial activities is one of the programs to be achieved MTs Muhammadiyah Baki, Sukoharjo in achieving the success of the learning process in terms of both students to improve learning outcomes and the teacher can be the science that has been learned that improve learning outcomes are achieved by the students.

In addition, to improve the quality of religious education, especially in subjects Qur'an Hadits which is part religious education curriculum that aims to achieve educational standards. And, one way to achieve maximum learning outcomes is needed Remedial Teaching in the learning process. Both, in general and the teaching programs of religious instruction assist the students in achieving the expected and in accordance with the standards.

In the implementation of Remedial Teaching was a follow-up process of teacher of Qur'an Hadits subject who sought help students overcome learning difficulties and can achieve the expected learning outcomes, appropriate description of the interview as follows: "Remedial was carried out in class if there are students with learning difficulties in order to achieve maximum results in the form of better learning outcomes again. And measures that we use is to provide guidance for students who have difficulty in reading, writing and understanding the Qur'an Hadits subject was done outside of school hours in order to achieve maximum results and for students who can also be expected to follow the guidance in order to improve academic achievement in the Qur'an Hadits subject. ${ }^{17}$

"From interviews can be concluded that the process of remedial teaching is done through a process of

\footnotetext{
17 Fathin Suryaning,S Ag, Guru Qur'an Hadits Kelas VIII MTs Muhammadiyah Waru Baki Sukoharjo, 25 Desember 2017.
}

guidance out of school hours, such as after school. And, mentoring the students is not only aimed at the students who have learning difficulties but also for students who are already proficient to further improve learning outcomes.

And material in the Qur'an Hadith subjects not only on writing, reading, memorization of Qur'an and hadith contains besides the necessary things that are related to both, in accordance with the results of interviews with subject teachers in grade VIII following Qur'an Hadith "in the delivery of materials provided by the teacher in the Qur'an hadith subjects have different ways according to the material provided, one of them with the provision of material tajwid as a way to facilitate the understanding of the students in the Qur'an and hadith as well as ease in write, understand and recite the Quran fluently and smoothly ". ${ }^{18}$

The process of understanding the Qur'an and the Hadits will be easier to understand and study the Qur'an Hadits which is not difficult to learn if there is a willingness to train themselves to studying the Qur'an and Hadits and its tajwid with people who are more proficient in learning the Qur'an and Hadits. Then, it will be easier to achieve better learning outcomes.

By holding Remedial Teaching program, it can help some students who have learning difficulties, especially on the subjects of Qur'an and Hadits. And, for the students who already know and understand the Qur'an, it can implement the content of the verses of the Qur'an.

The students' abilities of MTs Muhammadiyah Waru Baki, Sukoharjo are different. In the excellent class, it is only slightly students whose value is below the standard. In contrast to the

\footnotetext{
${ }^{18}$ Fathin Suryaning, S.Ag, Guru Qur'an Hadits Kelas VIII di MTs Muhammadiyah Waru Baki Sukoharjo, 25 Desember 2017.
} 
class that is not featured, in which their learning outcomes much less than the KKM (minimal standard value).

Based on the interview, the execution of remedial in MTs Muhammadiyah Baki, Sukoharjo is simultaneously done by giving the questions in the class that should be done by the students are exposed to such remedies. But for Qur'an Hadits subject of VIII class, before being given about the remedies, the teachers hold classes learning that aims to help the students who do not understand the material that has been described. After that, they are given the task in groups. Thus, among the students with one another work together and the students who do not understand the subject, can be assisted by his friends who already understand.

Related to the remedial tests, test grille is occasionally given only. However, it is certain that the questions of remedial easier than on the questions that previously tested. By the remedial program, the students' previous value, which is less good become better. So, they become a passion to follow. But, not all students who take the remedy get great value and above the KKM (minimum completeness criteria) in the reality. Some students' value is still under the average. So that teachers give special assignments to the students.

According to the information above, we can conclude that the process remedial teaching, especially on the subjects of Qur'an Hadith was already well underway.

To obtain data on remedial teaching using the curative approach in MTs Muhammadiyah Waru, Baki, Sukoharjo, the researcher also used questionnaires and the number of

\footnotetext{
19 Mulyadi, Dianogsis Kesulitan Belajar,
} (Yogyakarta : Nuha Litera, 2010), 53. respondents have been randomly assigned (randomized) by 60 students.

The questionnaire consists of 14 items and closed. Each question has an answer choice a, b, c, d, and e by scoring as follows:

a. The answer option (a) with a score of 4

b. The answer option (b) with a score of 3

c. The answer option (c) with a score of 2

d. The answer option (d) with a score of 1

e. The answer option (e) with a score of 0

From the questionnaire results, it is concluded that the implementation of remedial teaching in MTs Muhammadiyah Waru, Baki, Sukoharjo is always executed. This is shown in the table as much as 43 and has a percentage of $71.7 \%$.

\section{Discussion of Results}

The implementation of remedial teaching on the Qur'an Hadits subject in MTs Muhammadiyah Waru, Baki, Sukoharjo is executed based on the score of the students who have not completed SKL (graduated competence standard). From the research, it is agreed with Mulyadi's opinion (2010: 53) states that the remedial teaching can be implemented after the ongoing remedial learning programs in accordance with the competency standards (SKL) set, called the remedial using the curative approach. ${ }^{19}$

The teachers use the reference of benchmark assessment that is competency standards (SKL). On the subject of the Qur'an Hadith, SKL is set at 78 . The remedial program conducted by Fathin Suryaning, S.Ag and Mrs. 
Halimah was limited to the provision of questions after their evaluation. The students whose score under 78 are required for the remedial test.

The teacher's role is very important in mobilizing and motivating students to perform learning activities. Teachers are not only trying to attract the attention of students, but also increase the activity of students through the method in accordance with the conditions and abilities of students. In the implementation of remedial teaching, research shows that teachers carry out remedial at the right time and place so that students really feel ready and comfortable, so that students do not have learning difficulties and can reach SKL set.

Remedial teaching using the curative approach implemented in class VIII MTs Muhammadiyah Baki, Sukoharjo was held after the teachers know the results of the evaluation score of sub-theme 1 of all students. The visible symptoms are the result of learning which is lower than the level of success criteria / SKL set.

In the implementation, the students whose score is under the standard criteria are given for remedial. This is in accordance with the Mulyono's opinion (2010: 53) states that the main target of the curative remedial teaching is the students whose performance is far under that labored SKL can achieve the minimal completeness standard, and the students are still lacking a bit of an enhanced minimum completeness can be pursued. ${ }^{20}$

The learning method is one of the components in teaching and learning, a means to achieve the objectives with the support of teaching aids, and the needs of

20 Mulyono Abdurrahman, 2010. Pendidikan Bagi Anak Berkesulitan Belajar, (Jakarta: Rineka Cipta, 2010), 53. the education system, so it is necessary to determine the method to be used in the implementation of learning. In the selection of the methods, the teachers should consider learning objectives, instructional materials, teachers, students and the learning situation. The method implemented in the remedial is the whole activities of guiding learning difficulties ranging from the steps of identifying cases up to the following up steps(Mulyono, 2010: 53).

According Sugihartono, et al (2007: 178) methods that can be used in the implementation of remedial teaching,namely, assignments, discussions, question and answer, group work, peer tutoring and individualized instruction. The method to be used must be determined beforehand according to the type, nature and background of learning difficulties experienced by students. It can also be used to identify cases of students who are learning disabilities. ${ }^{21}$

Based on this research, the teacher uses the method of administration tasks and individual learning. The method is a method of assignment that teachers by giving specific tasks to students either in groups or individually, and then asked for accountability for the task. Determination of the type and nature of the task is adjusted to the type, nature and background of the learning difficulties encountered.

Implementation of the method of task administration is performed by the Qur'an Hadits teachers with no specialized task or problem in accordance with the difficulties of students, all students work on the same problem, both it is done at school and at home.

21 Sugihartono, dkk, Psikologi Pendidikan, (Yogyakarta: UNY Press, 2007), 178. 
Next, the teacher re-measures learning outcomes and re-evaluates the data values. And the results of the study, the students demonstrate the increase of learning outcome, but it has not fully adequate minimum expected as success criteria. This increase is seen from the results of the students' grades improved, although there are some students who have not yet reached SKL.

The next stage is assigned. Mulyadi (2010: 71) states that the recommendations can be given to students who have demonstrated improved performance by achieving specified SKL is to continue with the next step of learning program. For the students who show increased achievement, but not sufficient in accordance SKL, then, they are given a special program aimed at enrichment. ${ }^{22}$

In the educational goals, learning outcomes is a most fundamental thing, because the success or failure of the learning objectives depends on the student learning outcomes. The success of students is part of successful educational purposes that means if the student learning outcomes are good, the education objectives are certainly successful, otherwise if the student learning outcomes is less well, the education objectives cannot be said to be successful.

The teaching and learning process have always found the existence of a talented children, high capability, no less talented, slow response and quick response, not only their background but also different experiences. From these differences, we often encounter in the learning process the existence of the students who successfully achieve their satisfactory learning outcomes, but otherwise there are also the students who have not succeeded in learning and to be able to achieve the expected learning outcomes. From these problems, the students can be helped either individually or in groups to improve learning outcomes achieved in accordance with their ability.

One aid is implemented through the Remedial teaching is a form of a special teaching to improve the learning process. Remedial teaching is used to help the students who experience learning difficulties.

In this study, the researcher discuss is remedial teaching using curative approach. This approach is held to remember the fact that someone or some students, even all members of a study group was unable to complete the program perfectly based on the criteria for success in the learning process. Implementation of remedial teaching services can be provided individually if it turns out the students who need the help are in a limited number, and a control group (peers group) if it turns out in a number of students who have the type or nature of the difficulties together.

While, learning outcomes are a result of what has been done by the students. The students make various ways of effort to obtain a good performance. But, the fact is often not as expected where the student learning outcomes cannot necessarily be achieved well. This is influenced by several factors that determine the success of student learning, including the factors of the student or internal factors and the factors out of the student or external factors.

Achieving the maximum learning outcomes will require Remedial Teaching, by emphasizing on achieving the standards set by the value of each teaching program, both in general and religion, in helping the students to

${ }^{22}$ Mulyadi, Dianogsis Kesulitan Belajar, 71. 
achieve the expected learning outcomes, including the subjects of the Qur'an and Hadits.

Based on the results of the study, it is concluded that all 60 study subjects experienced an increase in learning outcomes, and 51 students called to be completed, i.e. the value is over the minimum completeness criteria (KKM), while only 9 students who did not complete after the holding of remedies, whose value is still under KKM (minimum completeness criteria).

Eighth grade students of MTs Muhammadiyah Waru, Baki, Sukoharjo have high motivation in terms of the desire to always follow the subsequent evaluation or upgrade the score. When it is held an extra lesson, many students also follow it. This indicates that the attitudes of the students in terms of learning on a positive direction. And from an increase of learner and student learning outcomes, it showed a major goal of the learning process in MTs Muhammadiyah Waru, Baki, Sukoharjo, because the success of the learning objectives is the purpose of education.

From the above results, the remedial teaching using curative approach in MTs Muhammadiyah Baki, Sukoharjo shows an influence, it can be seen on improving student learning outcomes.

\section{CONCLUSION}

Based on the results of the study and after analysed, it can be concluded that (1) Implementation of remedial teaching in MTs. Muhammadiyah Waru Baki Sukoharjo is $71.9 \%$, which means "good enough". (2) The results of the students' learning experience increase $68.46 \%$ from the average value of 69.46 into 85.37 with an increase percentage of $23 \%$. (3) From the test calculation of the normality and sample paired t-test, it is resulted that arithmetic $\mathrm{t}>\mathrm{t}$ table or
$19.025>2.001$ namely reject $\mathrm{H} 0$ and received $\mathrm{H} 1$, which means there are significant remedial teaching using the curative approach to improve the student learning outcomes in Qur'an Hadits lesson in MTs. Muhammadiyah Waru Baki, Sukoharjo.

\section{BIBLIOGRAPHY}

Abdur Rahman Ginting, the practical essence of teaching andlearning,(Bandung: Humanism, 2008).

Abin Syamsuddin Ma'mun, educationalpsychology,(Bandu ng: PT. Youth Rosdakarya, 2012).

Abu Ahmadi and Widodo Supriyono, psychology oflearning,(Jakarta: PT. Rineka copyright 2004).

Aina Mulyana, lihat di http://ainamulyana.blogspot.co. $\mathrm{id} / 2012 / 01 /$ pengertian- hasilbelajar-dan-faktor.html pada tanggal 012 november 2015.

Arief Furchan, Pengantar Penelitian dalam Pendidikan, (Surabaya: Usaha Nasional, 1982).

Burhan Bungin, Metode Penelitian Kuantitatif, (Jakarta: Kencana, 2010).

Cece Wijaya, Pendidikan Remidial Sarana Pengembangan Mutu Sumber Daya Manusia, (Bandung: PT. Remaja Rosdakarya, 2010).

Depag RI, GBPP Qur'an Hadits Madrasah Tsanawiyah, (Jakarta: Dirjen Kelembagaan Agama Islam, 1994).

Departemen Agama RI, Standar Kompetensi Madrasah Tsanawiyah, (Jakarta: Direktorat Jenderal Kelembagaan Agama Islam, 2004).

Departemen Agama RI,Standar Kompetensi Madrasah 
Tsanawiyah, (Jakarta:

Direktorat Jenderal

Kelembagaan Agama Islam Jakarta, 2004).

Hambal, Muhammad. 2018. Halaqah

Tradition in Building Rabbani Characters in Pesantren Al-

Islam Lamongan, East Java, Indonesia. Jurnal Studia Religia, Vol. 2, No. 1 . 2015. "Deresan" Program the Mastery of Arabic-Classic Book at Pondok Pesantren Karangasem Lamongan East Java Indonesia. Journal of Social Sciences and Humanities, Vol. 1, No. 2, pp. 125-130

Iqbal hasan, Analisis data penelitian statistic,(Jakarta:Bumi Aksara,2006).

Ischak SW, Program remedial dalam proses belajar mengajar, (Yogyakarta: Liberty, 1982).

Iskandar, Psikologi pendidikan, (Ciputat:Gaung persada press, 2009).

Margono, Metode Penelitian Pendidikan, (Jakarta: PT Rineka Cipta, 1997).

Margono, Metodologi Penelitian, (Jakarta: Rineka Cipta, 2003).

Martini Jamaris, Kesulitan belajar: Perspektif, asesmen, dan penanggulangannya bagi anak usia dini dan usia sekolah, (Bogor: Ghalia Indonesia, 2014).

Muhaimin, Et. el, Paradigma Pendidikan Islam, ( Bandung :PT. Remaja Rosdakarya, 2002).

Muhibbin syah, Psikologi pendidikan, (Bandung: PT. Remaja rosdakarya, 2013).

Mulyadi, Diagnosis Kesulitan Belajar dan Bimbingan terhadap Kesulitan Belajar Khusus
(Yogyakarta: Nuha Litera, 2008).

Mulyadi, Dianogsis Kesulitan Belajar, (Yogyakarta : Nuha Litera, 2010).

Mulyadi, Dignosis dan Pemecahan Kesulitan Belajar, (Malang: Shefa, 2003).

Mulyono Abdurrahman, 2010. Pendidikan Bagi Anak Berkesulitan Belajar, (Jakarta: Rineka Cipta, 2010).

Nana Sudjana, Penilaian Hasil Proses Belajar Mengajar, (Bandung: Remaja Rosdakarya, 2009).

Nana Syaodih Sukmadinata, Metodologi Penelitian Pendidikan, (Bandung: Remaja Rosdakarya, 2009).

Nana Syaodiq Sukmadinata, Landasan Psikologi Proses Pendidika, (Bandung: PT. Remaja Rosdakarya, 2003).

Oemar Hamalik, Metoda Belajar dan Kesulitan Belajar, (Bandung: Tarsito, 1983).

Oemar Hamalik, Perencanaan Pengajaran berdasarkan Pendekatan Sistem, (Jakarta. Bumi aksara, 2003).

Oemar Hamalik, Perencanaan pengajaran, (Jakarta: Bumi Aksara, 2002).

Purwanto, Evaluasi Hasil Belajar, (Yogyakarta: Pustaka Pelajar, 2011).

Rochman Natawijdaya, Pengajaran Remedial, (Jakarta: Departemen Pendidikan dan Kebudayaan 1980).

S. Margono, Metode Penelitian Pendidikan, (Jakarta: Asdi Mahasatya, 2004).

Slameto, Belajar dan Faktor-faktor yang mempengaruhinya, (Jakarta: Rineka Cipta, 1991).

Sugiyono, Statistika untuk Penelitian (Bandung: Alfabeta, 2006). 
Suharsimi Arikunto, Prosedur Penelitian Suatu Pendekatan Praktik, (Jakarta: PT Rineka Cipta, 2010).

Suharsimi Arikunto, Prosedur Penelitian;Suatu Pendekatan Praktik, (Jakarta: Rineka Cipta, 1993).

Suharsimi Arikunto, Prosedur penenlitian suatu pendekatan praktek, (Jakarta: Rineka cipta, 1997).

Sukardi, Evaluasi pendidikan prinsip dan operasionalnya, (Jakarta: Bumi Aksara, 2012). 